Article

\title{
Nanostructured Zn-Substituted Monetite Based Material Induces Higher Bone Regeneration Than Anorganic Bovine Bone and $\beta$-Tricalcium Phosphate in Vertical Augmentation Model in Rabbit Calvaria
}

\author{
Lorena Benito-Garzón ${ }^{1, *(1)}$, Yasmina Guadilla ${ }^{2}\left(\mathbb{D}\right.$, Idoia Díaz-Güemes ${ }^{3}$, Iván Valdivia-Gandur ${ }^{4}(\mathbb{D}$, \\ María-Cristina Manzanares ${ }^{5}\left(\mathbb{D}\right.$, Arcadio García de Castro ${ }^{6,7}$ and Sussette Padilla ${ }^{6,8}$ (D) \\ check for \\ updates \\ Citation: Benito-Garzón, L.; Guadilla, \\ 1 Departamento de Anatomía e Histología Humanas, Facultad de Medicina, Universidad de Salamanca, \\ 37007 Salamanca, Spain \\ 2 Departamento de Cirugía, Facultad de Medicina, Universidad de Salamanca, 37007 Salamanca, Spain; \\ yguadilla@usal.es \\ 3 Centro de Cirugía de Mínima Invasión Jesús Usón, 10071 Cáceres, Spain; idoiadiaz@ccmijesususon.com \\ 4 Departamento Biomédico, Facultad de Ciencias de la Salud, Universidad de Antofagasta, \\ Antofagasta 1270300, Chile; ivan.valdivia@uantof.cl \\ 5 Departamento de Anatomía y Embriología Humanas, Universidad de of Barcelona, 08007 Barcelona, Spain; \\ mcmanzanares@ub.edu \\ 6 AzureBio S.L., Tres Cantos, 28760 Madrid, Spain; agc@qube.org (A.G.d.C.); spadilla@farm.ucm.es (S.P.) \\ 7 Fundación QUBE, Tres Cantos, 28760 Madrid, Spain \\ 8 Departamento de Quimica en Ciencias Farmacéuticas, Facultad de Farmacia, \\ Universidad Complutense de Madrid, 28040 Madrid, Spain \\ * Correspondence: lorenabenito@usal.es
} Y.; Díaz-Güemes, I.; Valdivia-Gandur, I.; Manzanares, M.-C.; de Castro, A.G.; Padilla, S. Nanostructured Zn-Substituted Monetite Based Material Induces Higher Bone Regeneration Than Anorganic Bovine Bone and $\beta$-Tricalcium Phosphate in Vertical Augmentation Model in Rabbit Calvaria. Nanomaterials 2022, 12, 143. https://doi.org/10.3390/ nano12010143

Academic Editor: Zili Sideratou

Received: 2 November 2021

Accepted: 24 December 2021

Published: 31 December 2021

Publisher's Note: MDPI stays neutral with regard to jurisdictional claims in published maps and institutional affiliations.

Copyright: (C) 2021 by the authors. Licensee MDPI, Basel, Switzerland. This article is an open access article distributed under the terms and conditions of the Creative Commons Attribution (CC BY) license (https:/ / creativecommons.org/licenses/by/ $4.0 /)$.
Abstract: The capacity of a nanostructured multicomponent material composed of Zn-substituted monetite, amorphous calcium phosphate, hydroxyapatite and silica gel (MSi) to promote vertical bone augmentation was compared with anorganic bovine bone (ABB) and synthetic $\beta$-tricalcium phosphate $(\beta-\mathrm{TCP})$. The relation between biological behavior and physicochemical properties of the materials was also studied. The in vivo study was conducted in a vertical bone augmentation model in rabbit calvaria for 10 weeks. Significant differences in the biological behavior of the materials were observed. MSi showed significantly higher bone regeneration (39\%) than ABB and $\beta$-TCP (24\%). The filled cylinder volume was similar in MSi (92\%) and ABB (91\%) and significantly lower in $\beta$-TCP $(81 \%)$ implants. In addition, $\beta$-TCP showed the highest amount of non-osteointegrated particles (17\%). MSi was superior to the control materials because it maintains the volume of the defect almost full, with the highest bone formation, the lowest number of remaining particles, which are almost fully osteointegrated and having the lowest amount of connective tissue. Besides, the bone formed was mature, with broad trabeculae, high vascularization and osteogenic activity. MSi resorbs gradually over time with an evident increment of the porosity and simultaneous colonization for vascularized new bone. In addition, the osteoinductive behavior of MSi material was evidenced.

Keywords: monetite; zinc; hydroxyapatite; silica gel; amorphous calcium phosphate; vertical bone augmentation; bone regeneration; anorganic bovine bone; $\beta$-tricalcium phosphate

\section{Introduction}

Teeth may be lost by dental disease, trauma, or as a consequence of a surgical procedure to resect part of a jaw pathologically damaged. Teeth also may be congenitally absent. After teeth loss, there is a lack of supporting bone due to atrophy, trauma, failure to develop, surgical resection, or infectious diseases, such as advanced periodontitis. This could be a problem for both implants and removable prostheses [1], which are getting loose by bone resorption. 
Dental implants can only be implanted if there is enough healthy bone to stabilize them adequately. If not, bone augmentation is mandatory before implant placement. However, vertical bone augmentation is a major surgical clinic challenge and is not always achieved [2]. In particular, repairing the resorbed alveolar ridge in the edentulous posterior maxilla is one of the most critical challenges in modern dentistry [3]. The maxillary sinus, the nasal cavity, and the mandibular inferior alveolar nerve limit the bone height for proper implant placement. Several techniques are used for vertical bone augmentation, and usually, a high of $9 \mathrm{~mm}$ or more is necessary. Surgical procedures used for bone volume augmentation include guided bone regeneration, onlay or inlay grafting, ridge expansion and distraction osteogenesis. These techniques are usually associated with a donor site requirement, high complication rate, low success rate and inconsistent results $[2,4]$.

For bone augmentation, it is necessary to use a fill material, like autogenous bone, allograft, xenograft, and synthetic bone grafts. Autogenous bone grafting remains the gold standard graft material. It is the most frequently used technique for vertical augmentation, despite its significant disadvantages, such as the requirement of bone harvesting and morbidity at the donor site, which includes pain, a potential infection, and loss of function [5,6]. A limited amount of intraoral bone makes harvesting and grafting challenging, and autologous bone grafts from other sites may not be suitable for dental implantation due to poor quality. In addition, the complications associated with autogenous iliac grafts are significant [7]. Attempts have been made to improve graft survival and volumetric maintenance. Calvarial bone has been reported to be superior to the iliac bone for onlay grafting because of decreased resorption, and it has been presented as a possible alternative method to achieve maxillary augmentation and sinus elevation [8]. Different biomaterials to replace bone autografts have been investigated in many animal and clinical studies [9-16] to overcome the mentioned bone harvesting drawbacks.

Bone augmentation procedures may be carried out before implant placement (twostage procedure), or at the same time as implant placement (one-stage procedure), using different materials and techniques. An additional surgical episode is needed when carried out before placement, and the area is left to heal for some time before the implants are placed. Altogether, the ideal treatment for vertical bone augmentation should be the least invasive as possible. Therefore, it should not include an additional surgery for bone harvesting, and a two-step procedure involving two surgeries should be avoided.

The surgical technique combined with biomaterials, including bone graft and membranes, must ensure the maintenance of augmented bone volume over time. For this purpose, bone graft materials and membranes should become an effective alternative to autologous bone. They should be replaced by new bone, ensuring a high bone volume augmentation and conservation over time.

Allogenic bone from donor patients or xenograft materials has been used as an alternative to autologous bone. The most used xenograft material in implantology is an organic bovine bone (ABB). It is composed of hydroxyapatite (HAp), the mineral part of the bone. $\mathrm{ABB}$ is considered a very slow resorbed material that provides long-term volume preservation of augmented ridge [17-20]. However, non-resorbable or very slowly resorbable materials compromise the ultimate goal of complete regeneration of bone defects and may interfere with the integration of endosseous implants [21]. More resorbable synthetic calcium phosphates, such as $\beta$-tricalcium phosphate $(\beta-T C P)$ are also frequently used in the clinic. Still, it is often associated with a loss of bone defect volume [22]. To assurance long-term preservation, materials combining HAp and TCP with different ratios have demonstrated good osteoconductivity and volume-maintaining capacity [23]. Bioactive glasses, usually composed of $\mathrm{SiO}_{2}, \mathrm{Na}_{2} \mathrm{O}, \mathrm{CaO}$ and $\mathrm{P}_{2} \mathrm{O}_{5}$ have also been used as bone graft substitutes [24]. These materials are distinguished by their capacity of inducing new bone formation. Their resorption times depend on their composition.

Recently we have developed a new family of nanostructured materials combining calcium phosphates with different resorption rates: monetite, amorphous calcium phosphate and hydroxyapatite with silica gel [25-27]. These biomaterials were designed for 
acting like a temporary scaffold for bone growth, being gradually replaced by the newly formed bone and providing a local enrichment environment with ionic species, such as calcium, silica, phosphorus that favors bone regeneration. They have chemical and physical characteristics resembling the mineral part of the bone, such as nanostructure, composition, high specific surface area and porosity. The influence of HAp/Monetite ratio to achieve the best performance in bone regeneration was studied [26].

Zinc has been reported to induce osteoblastogenesis, osteoblast mineralization and to inhibit osteoclastic activity [28-35]. Therefore, Zn was incorporated in the material by partially substituting calcium in the monetite (MSi) [27].

This material effectively regenerates critical bone defects in sheep with significant resorption and replacement by new active and mature bone, both outside and inside granulates, with a high degree of vascularization and abundant osteogenic activity. It was also demonstrated that these materials induce bone formation and vascularization [26].

In addition, the material porosity increases after implantation, giving rise to a pore size compatible with vessel ingrowth [36]. Previous in vivo study in critical defects in sheep showed that MSi effectively restored bone volume and regenerated the defect being simultaneously replaced by new active bone [27]. In addition, the influence of HAp/Monetite ratio to promote bone formation was studied [26].

This work aimed to evaluate the vertical bone augmentation and bone regeneration capacity of a novel biomaterial (MSi) composed of Zn-substituted monetite, amorphous calcium phosphate, tricalcium phosphate and hydrated silica gel compared with two widely used bone graft materials, ABB and $\beta$-TCP. An osteoconductive model in titanium cylinders implanted in rabbit calvaria after 10 weeks was conducted. Their bone regeneration capacity and replacement by new osseous tissue were evaluated.

\section{Materials and Methods}

\subsection{Studied Biomaterials}

Three commercial granules were evaluated. Anorganic Bovine Bone ABB (Bio-Oss ${ }^{\circledR}$ ) from Geistlich Pharma AG, Wolhusen, Switzerland, $\beta$-TCP (Cerasorb ${ }^{\circledR}$ ) from Curasan AG, Kleinostheim, Germany and MSi (Sil-Oss ${ }^{\circledR}$ ) from Azurebio SL, Madrid, Spain. ABB and MSi granulates were available with sizes between $0.25-1 \mathrm{~mm}$ and $\beta-\mathrm{TCP}$ granulates ranged between $0.5-1 \mathrm{~mm}$.

$\mathrm{ABB}$ is obtained by protein extraction from bovine bone, and the $\beta$-TCP is a synthetic material produced by sintering. On the other hand, MSi is synthesized by a low-temperature process involving a hydraulic cementation reaction as previously described [25-27].

\subsection{Biomaterials Characterisation}

Materials were characterized as received by X-ray powder diffraction (XRD), scanning electron microscopy (SEM), $\mathrm{N}_{2}$ adsorption porosimetry and $\mathrm{Hg}$ porosimetry.

XRD patterns were recorded using a D8 Advance (Bruker AXS, Billerica, MA, USA) $X$-Ray diffractometer with LinxEye Super Speed Detector. The recording conditions were $10-70^{\circ}(2 \theta)$, step size $0.05^{\circ}(2 \theta)$, step time $1.05 \mathrm{~s}, \lambda \mathrm{CuK} \alpha 1=1.54056 \AA$, Va $=40 \mathrm{kV}$ and $\mathrm{Ia}=40 \mathrm{~mA}$.

Biomaterials surface microstructure was examined on gold-coated samples using a TM-1000 table microscope (Hitachi Hi-Tech, Tokyo, Japan).

Specific surface area measurements were performed in a Monosorb Surface Area Analyser by $\mathrm{N}_{2}$ adsorption at $-196{ }^{\circ} \mathrm{C}$ using the one-point BET method (MS-13, Quantachrome Instruments, Boynton Beach, FL, USA). Open porosity was determined in a Hg-intrusion porosimeter in the pore diameter range of 300 to $0.007 \mu \mathrm{m}$ (PoreMaster 33, Quantachrome Instruments, Boynton Beach, FL, USA).

\subsection{Experimental Animal Model}

The animal experimentation was performed according to the national guidelines and conducted following the Spanish law (RD53/2013). Besides, the animal study was 
approved by the ethical committee for animal experiments of the Centro de Cirugía Minima Invasiva Jesus Usón (035/11) (Caceres, Spain) where in vivo experiments were carried out. Moreover, experiments were conducted according to European Communities Council Directive (2010/63/EU) and measures were taken to minimize pain or discomfort and animal suffering.

Eight New Zealand female rabbits aged between 8 and 9 months weighing $4.6 \pm 0.2 \mathrm{Kg}$ were premedicated with $0.25 \mathrm{mg} / \mathrm{Kg}$ intravenous midazolam (Midazolam Normon, Laboratorios Normon, Madrid, Spain) via the marginal ear vein. Then anesthesia was induced with 1 to $1.5 \mathrm{mg} / \mathrm{Kg}$ intravenous alfaxalone (Alfaxan, Jurox Limited, Dublin, Ireland). Orotracheal intubation was performed, and animals were connected to a ventilator. The anesthetized state was maintained with sevoflurane (Sevorane, Abbott Laboratories, Madrid, Spain) in oxygen $\left(\mathrm{FiO}_{2}=1\right)$ at $3 \mathrm{~L} / \mathrm{min}$ initial fresh gas flow rate (FGF) until 3-3.5\% of sevoflurane in the expelled gas was reached followed by $0.5 \mathrm{~L} / \mathrm{min}$ FGF. Mechanical ventilation was set at $20-25 \mathrm{rpm}$ with a volume of $5-10 \mathrm{~mL} / \mathrm{Kg}$ until normal values (35-40 mm $\mathrm{Hg}$ ) were reached. Intravenous analgesia was carried out by ketorolac (Toradol, Atnahs Pharma Netherlands, Kovenhavn, Denmark) $(1.75 \mathrm{mg} / \mathrm{Kg}$ ) and tramadol (Adolonta inyec., Grünenthal Pharma, Madrid, Spain) (3 mg/Kg). Throughout the surgery, animals were infused intravenously with $5 \mathrm{~mL} / \mathrm{Kg} / \mathrm{h}$ of $0.9 \%$ saline. Heartbeat, hemoglobin saturation and respiratory frequency were monitored.

Animals were placed in sternal recumbency, the head was shaved, and the cutaneous surface was disinfected with a povidone iodine solution. Calvaria bone was exposed through a $5 \mathrm{~cm}$ skin incision over the media line. Four circular osteotomies, $2 \mathrm{~mm}$ in depth, were carried out in the parietal bone for each animal, two anterior and two posterior at each side of the median sagittal suture. A $6 \mathrm{~mm}$ diameter and $0.5 \mathrm{~mm}$ thick trephine and a slow-speed electric handpiece with irrigation were used. Cortical bone was removed using a $3 \mathrm{~mm}$ surgical mono bevel chisel. Sterile grade 2 (ASTM B438) titanium rings with an internal diameter of $5 \mathrm{~mm}, 0.5 \mathrm{~mm}$ thick and $4 \mathrm{~mm}$ high, custom made by Lowde Titanium (Mallorca, Spain), were placed in each bone defects (Figure 1). MSi, $\beta$-TCP and ABB granules were randomly packed into the fitted cylinders up to the rim, and a blind code was assigned to each location. Subcutaneous tissues were closed with resorbable suture $3 / 0$, and skin was relocated with 3/0 silk suture. Postoperatively, buprenorphine (Bupac, Richter Pharma, Wels, Austria) (0.004 mg/Kg/12 h) and metoclopramide (Metroclopramida Kerpharma, Terrasa, Barcelona, Spain) $(0.5 \mathrm{mg} / \mathrm{Kg} / 12 \mathrm{~h})$ were administered subcutaneously as an analgesic for 3 days. Anti-inflammatory and antibiotic treatments with carprofen (Rimadyl, Zoetis, Madrid, Spain) (2 mg/Kg/12 h) and enrofloxacin (Baytril, Bayer Animal Health, Leverkusen, Germany) $(7 \mathrm{mg} / \mathrm{Kg} / 24 \mathrm{~h})$, were administered subcutaneously for 7 days.
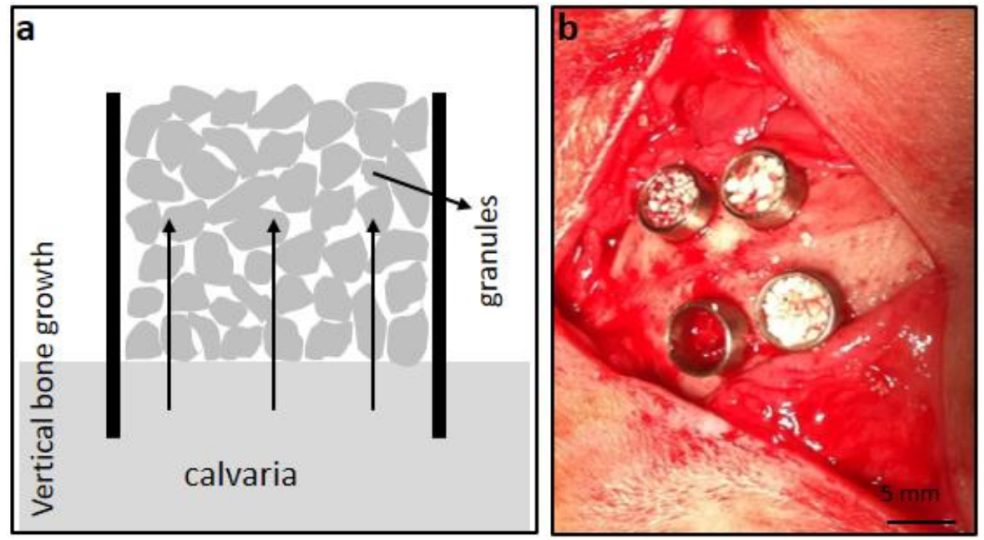

Figure 1. (a) schematic representation of vertical bone augmentation model using titanium rings in rabbit calvaria. (b) Four titanium rings ( $4 \mathrm{~mm}$-height and $5 \mathrm{~mm}$-diameter) were implanted in the rabbit calvaria filled with the studied granules. 
After general anesthetic by potassium chloride intravenous injection, animals were sacrificed at 10 weeks after surgery. Explanted samples, including implanted cylinder and underlying cranial bone, were obtained with an axe saw fitted with a carborundum disc. Samples were individually stored in $70^{\circ}$ ethanol and code labeled.

\subsection{Micro-CAT Scan}

Micro Computer Aided Tomography (Micro-CAT) was carried out before the histological processing to determine the bone volume formed within the rings. It was performed on explanted samples by Trabeculae S.L (Orense, Spain) using an X-ray microtomography SkyScan 1172 (Bruker microCT NV, Kontich, Belgium). The parameters for the measurements were adjusted in order to minimize the strong $X$-ray absorption for titanium: the voltage was set to $100 \mathrm{KV}$, intensity to $100 \mu \mathrm{A}$, nominal resolution $10 \mu \mathrm{m}$, sample rotating angle $0.4^{\circ}$, frame averaging of 4 , random movement of 25 , rotation angle of $360^{\circ}$ and filters of $\mathrm{Al}+\mathrm{Cu}$. Each sample was scanned for $5 \mathrm{~h}$. The obtained tomograms were reconstructed using the Feldkamp algorithm modified in the application NRecon version 1.6.1.7 (Bruker microCT, Kontich, Belgium). Ring artifacts reduction of 20 and a beam hardening correction of 20 were applied.

\subsection{Histological Evaluation}

After micro-CAT analysis, the explanted samples were gradually dehydrated in ethanol solutions of increasing concentrations ranging from 70 to $100 \%$. After dehydration, the samples were embedded in methyl methacrylate resin.

Samples were subjected to nondecalcified ground sectioning. The obtained blocks were cut with a low-speed saw microtome (Isomet, Bueher ${ }^{\circledR}$ lake bluff, Dusseldorf, Germany) parallel to the titanium cylinder axis to get central sections. Some sections were stained directly with Stevenel's Blue and van Gieson's picro-fuchsin that stains mineralized bone in red, non-mineralized organic matrix in blue and biomaterial in grey [37]. The histological examination was carried out with a light microscope Nikon eclipse 90i fitted with a camera Nikon digital Sight DS-SMc (Nikon Instruments Inc., Melville, NY, USA).

\subsection{Backscattering Electron Microscopy (BS-SEM)}

Some sections of cylinders were photographed using backscatter electron microscopy (BS-SEM) and INCA software (version 1.1.0.34) (Oxford instruments, Abingdon, United Kingdom). BS-SEM imaging was employed to highlight the contrast among the resin, bone, and biomaterials. Usually, resin appeared black, bone was grey, and the biomaterial had a brighter contrast than bone.

\subsection{Histomorphometric Analysis}

The top of the implant, generally free of bone, showed density artifacts caused by $\mathrm{Ti}$, therefore, $0.5 \mathrm{~mm}$ under cylinder top were discarded for micro-CAT analysis. X-ray absorption of Ti cylinder is very high; thus, its edges were observed poorly defined and blurred. This would cause an overestimation of bone during the binarization of images. In addition, it is known the osteoconductive behavior of $\mathrm{Ti}$ and bone growth through the inner cylinder surface was observed. Therefore, to avoid overestimation in the quantification of bone formed, $0.2 \mathrm{~mm}$ from the inner walls of the Ti cylinder inwards was discarded.

Therefore, to avoid overestimation in the quantification of the bone formed, $0.2 \mathrm{~mm}$ from the inner walls of the Ti cylinder inwards was discarded.

Thus, the total volume or volume of interest was considered as a cylinder of variable height depending on the depth to which the cylinder was implanted, with the upper limit $0.5 \mathrm{~mm}$ below the top edge of the cylinder with a $4.7 \mathrm{~mm}$ diameter inside the implant. Calvaria surface lines were analyzed to discard the previously existing bone and define the height at which the cylinder was implanted. Total volume includes new bone (NB), residual material (RM), intertrabecular spaces and connective tissue (CT). As occupied cylinder volume $(\mathrm{OV})$ was considered the volume where the mineralized matrix was present also 
including intertrabecular spaces and residual material. Percentages of OV were calculated relative to total volume.

Percentages of new bone (\% NB) and remaining material (\% osteointegrated or $\%$ non-osteointegrated material) were calculated from the histological images. These analyses were carried out on longitudinal histology central sections of the defect. ImageJ software (version 1.49) was used for the histomorphometric study.

Statistical analysis was carried out by non-parametric two-tailed Mann-Whitney U Test, for a level of significance $\leq 95 \%(\alpha \leq 0.05)$. Percentages are presented as averages \pm standard deviation $(\mathrm{AVG} \pm \mathrm{SD})$ (see Table 1$)$.

Table 1. Histomorphometric determinations and Mann-Whitney significance test. Average \pm standard deviations (SD) expressed as \% of total cylinder volume for ABB, $\beta$-TCP and MSi. Significance was determined by the non-parametric two-tailed Mann-Whitney $\mathrm{U}$ test for the significance level: 90 . $(\alpha \leq 0.1), \leq 95 \%(\alpha \leq 0.05)$ or $\leq 98 \%(\alpha \leq 0.02)$.

\begin{tabular}{|c|c|c|c|c|c|}
\hline Average \pm SD & $\begin{array}{c}\% \text { Occupied } \\
\text { Space }\end{array}$ & $\%$ New Bone & $\begin{array}{c}\text { \% Integrated } \\
\text { Material }\end{array}$ & $\begin{array}{c}\text { \% Non- } \\
\text { IntegratedMaterial }\end{array}$ & $\begin{array}{c}\text { \% Connective } \\
\text { Tissue }\end{array}$ \\
\hline $\mathrm{ABB}(n=7)$ & $91 \pm 13$ & $23.6 \pm 7.3$ & $22 \pm 10$ & $9.2 \pm 5.8$ & $31 \pm 10$ \\
\hline$\beta$-ТCP $(n=8)$ & $80.9 \pm 9.1$ & $24 \pm 15$ & $18 \pm 12$ & $17 \pm 18$ & $35 \pm 12$ \\
\hline $\operatorname{MSi}(n=7)$ & $91.7 \pm 2.9$ & $39 \pm 14$ & $15.6 \pm 7.5$ & $2.2 \pm 5.6$ & $18 \pm 11$ \\
\hline \multicolumn{6}{|c|}{ Mann-Whitney (N.S: Non Significant) } \\
\hline ABB vs. $\beta$-TCP & $\alpha \leq 0.05$ & N.S & N.S & N.S & N.S \\
\hline ABB vs. MSi & N.S & $\alpha \leq 0.1$ & N.S & $\alpha \leq 0.02$ & $\alpha \leq 0.05$ \\
\hline MSi vs. $\beta-\mathrm{TCP}$ & $\alpha \leq 0.05$ & $\alpha \leq 0.1$ & N.S & N.S & $\alpha \leq 0.02$ \\
\hline
\end{tabular}

\section{Results}

\subsection{Material Characterisation}

Studied biomaterials showed different compositions, morphology, porosity and specific surface area.

\subsubsection{Composition}

ABB is composed only of low-crystallinity hydroxyapatite, characteristic of biological hydroxyapatite (Figure 2 ). $\beta$-TCP is also a single-component material consisting of $\beta$ tricalcium phosphate with high crystallinity (Figure 2).

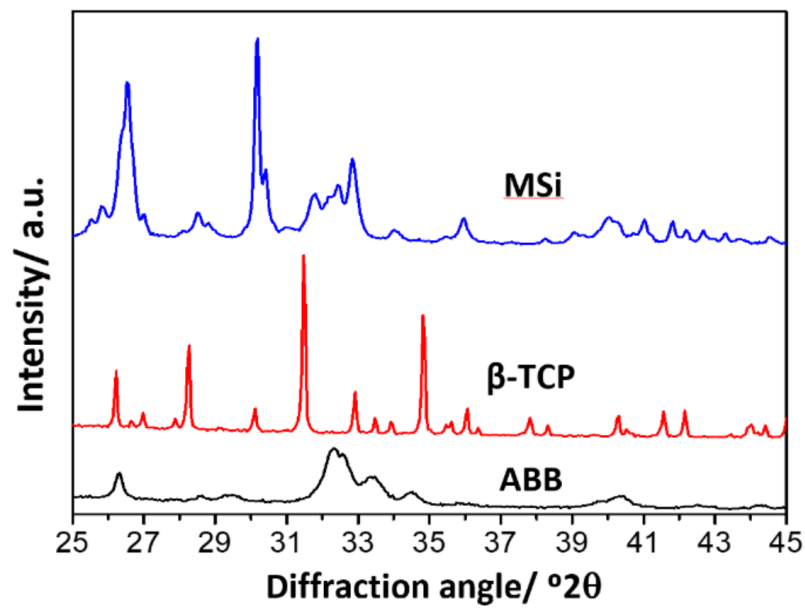

Figure 2. XRD pattern of studied materials. ABB is composed of low-crystallinity hydroxyapatite and $\beta$-TCP of pure $\beta$-tricalcium phosphate. MSi contains Zn-substituted monetite and hydroxyapatite as crystalline phases. It also contains amorphous calcium phosphate and hydrated silica gel [27]. 
On the contrary, MSi is a multicomponent material, showing XRD maxima corresponding to monetite and hydroxyapatite (Figure 2). A previous work [27] demonstrated that calcium in the monetite is partially substituted by $\mathrm{Zn}$ at 4 atom \%, corresponding to $1.1 \mathrm{wt} \%$. The incorporation of $\mathrm{Zn}$ caused shrinkage in the parameters and volume of the triclinic monetite cell unit and reduced the crystal domain size significantly compared with the material without $\mathrm{Zn}$. The MSi composition is $\mathrm{Zn}$-substituted monetite (57 wt $\%$ ), hydroxyapatite (25 wt\%), amorphous calcium phosphate $(11 \mathrm{wt} \%)$ and hydrated silica gel (7 wt \%).

\subsubsection{Microstructure, Porosity and Specific Surface Area}

ABB granulates had an irregular shape with sharp edges. The material microstructure is characterized by elongated fibers and micropores through the material surface (Figure 3). These pores showed two morphologies: rounded of $1.6 \mu \mathrm{m}$ diameter and the elongated ones of an average size of $6 \mu \mathrm{m}$ long and $0.34 \mu \mathrm{m}$ high (Figure 3). According to mercury porosimetry, the interconnection between these pores is smaller, with pores ranging between 200-7 nm, with a maximum centered at $40 \mathrm{~nm}$ (Figure $4 \mathrm{a}$ ). The fibrous microstructure and the micro and nanopores observed by SEM and Hg porosimetry are due to spaces left by the collagen fibers during the deproteinization process of the treated bone [28-39]. Besides, some isolated macropores with sizes ranging between 130-20 $\mu \mathrm{m}$ (average size: $50 \mu \mathrm{m}$ ) were also observed by SEM, corresponding to spaces left by the Haversian blood vessel systems.

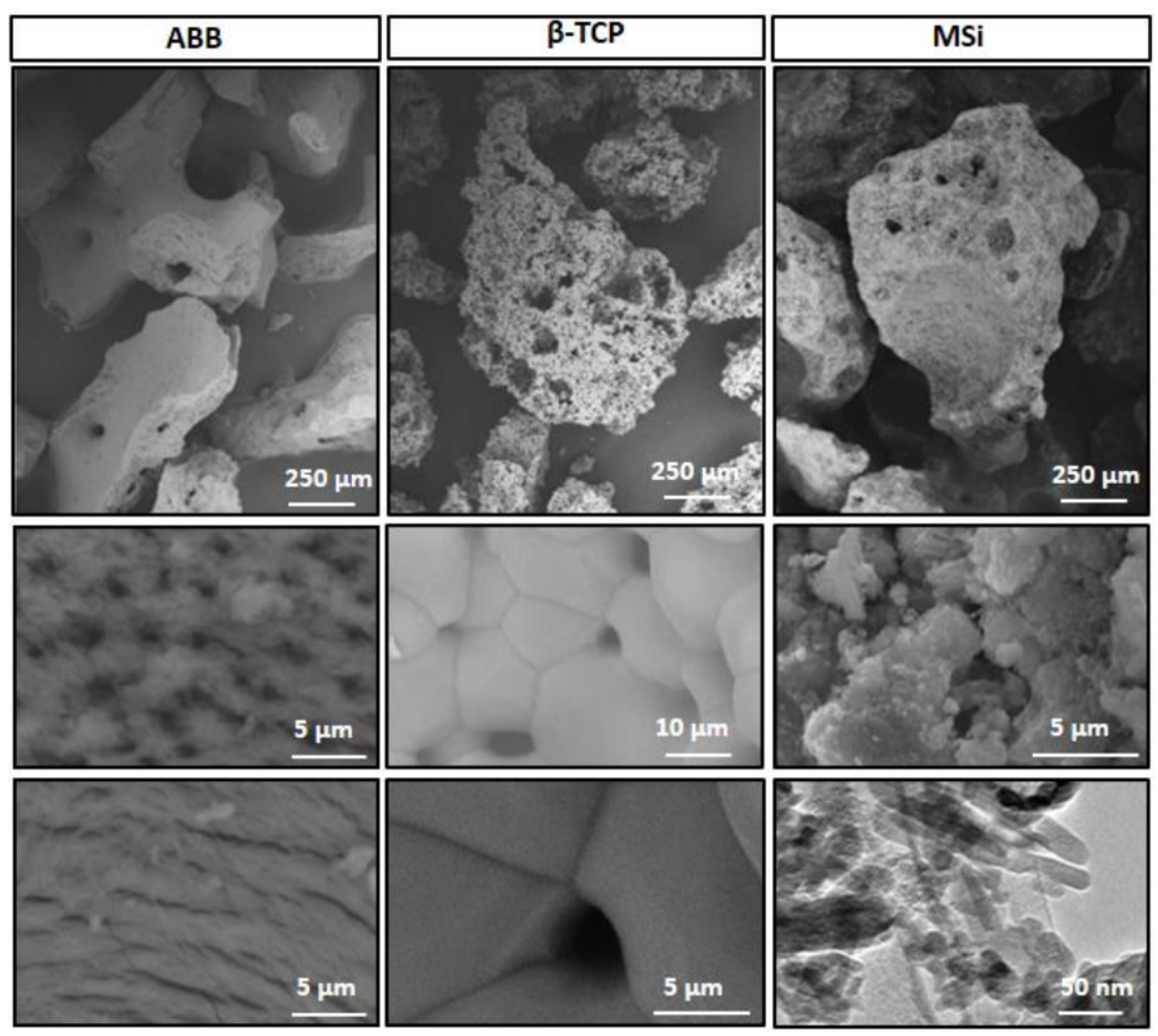

Figure 3. SEM micrograph of the studied materials. Granules had irregular shapes with sharper edges in $\mathrm{ABB}$ and smooth edges in $\beta$-TCP and MSi. ABB particles showed a porous surface with two pore morphologies. $\beta$-TCP showed the typical morphology of sintered materials with pores between grain boundaries. MSi showed a rough surface formed by agglomerates of similar porous morphology. These agglomerates are formed by homogeneously distributed nanometric particles, as observed in TEM images at the bottom right of the figure. 

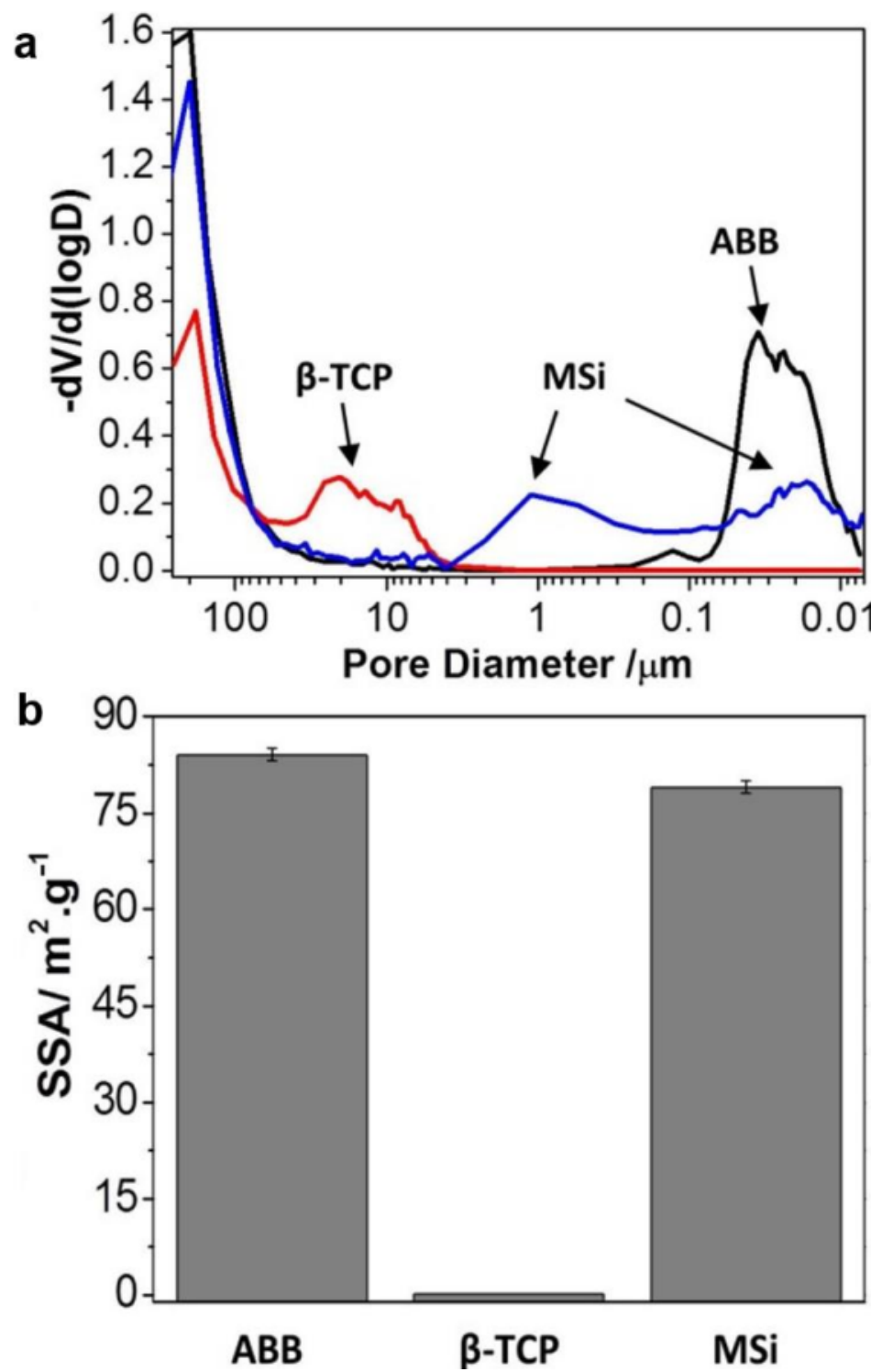

Figure 4. (a) Granules pore size distribution. ABB and MSi showed a similar total porosity but with different pore size distribution. ABB only showed nanometric pores whereas MSi had pores in a wider range, from micro to nanopores. $\beta$-TCP had the lowest porosity with the largest pore size, without pores in the meso or nanometric range. (b) ABB and MSi show a high specific surface area (SSA) of $80 \mathrm{~m}^{2} / \mathrm{g}$ whereas for $\beta$-TCP it is very low.

$\beta$-TCP granules also have irregular shapes but smooth edges and a porous microstructure. $\beta$-TCP shows a characteristic morphology of sintered materials with grains of high density and smooth surface (Figure 3). In addition, SEM revealed pores between 130-50 $\mu \mathrm{m}$ at the material surface with an average size of $70 \mu \mathrm{m}$ (Figure 3 ). $\beta$-TCP has the largest intragranular pore ranging between $30-3 \mu \mathrm{m}$, with a maximum of $20 \mu \mathrm{m}$ but does not have pores lower than $3 \mu \mathrm{m}$ (Figure $4 \mathrm{a}$ ). The high interconnected porosity of this material is due to the remaining pores between grains after sintering.

MSi presented a homogeneous and intimate distribution of its different components of nanometric size (Figure 3) as stated in previous work [27]. This material also showed irregular shapes with smooth edges and a rough, porous surface (Figure 3). SEM revealed the presence of macropores and mesopores both superficially and inside of granulates between 215-15 $\mu \mathrm{m}$ (average size: $53 \mu \mathrm{m}$ ) (Figure 3). Granules surface is formed by homogeneously distributed rounded agglomerates of similar morphology. These agglomerates provide microporosity $(3.5-0.15 \mu \mathrm{m})$ (Figure $4 \mathrm{a}$ ) and roughness homogenously distributed 
throughout the surface and inside the material. MSi has smaller pores (10 $\mu \mathrm{m}$ to $7 \mathrm{~nm})$ with two maxima centered at $1 \mu \mathrm{m}$ and $20 \mathrm{~nm}$ (Figure 4a).

The three studied materials also showed pores, by $\mathrm{Hg}$ porosimetry, higher than $60 \mu \mathrm{m}$ with maxima around $200 \mu \mathrm{m}$, corresponding to intergranular spaces left between neighboring granules after packing (Figure 4a).

According to the bulk density of the materials and the $\mathrm{Hg}$ porosimetry, the intergranular porosity of the three materials was similar (32 vol\%). The intragranular porosity of ABB and MSi was also similar (48 vol\%). However, $\beta$-TCP showed the lowest intragranular porosity being only $32 \mathrm{vol} \%$.

ABB and MSi showed a high specific surface area (SSA) $\left(86\right.$ and $80 \mathrm{~m}^{2} / g$, respectively) consistent with their porous structure. In contrast, $\beta$-TCP has a very low specific surface area $\left(<1 \mathrm{~m}^{2} / \mathrm{g}\right)$ (Figure $4 \mathrm{~b}$ ) characteristic of the sintering process and to the absence of both micropores lower than $3 \mu \mathrm{m}$ and nanopores.

\subsection{In Vivo Evaluation}

$\mathrm{ABB}, \beta-\mathrm{TCP}$ and MSi granules, with different resorption rates, were implanted in titanium rings in a vertical bone augmentation model in rabbit calvaria to study their bone regeneration capacity.

No post-surgical complications occurred except in one implant of $A B B$ and other of $\mathrm{MSi}$, where necrosis was observed at the implanted site so were discarded. Another ABB cylinder was broken during histological processing.

For the statistical analysis, two samples (ABB and $\mathrm{MSi}$ ) were discarded as they presented a totally different behavior from the rest of the samples, which showed a homogeneous behavior.

\subsubsection{Histomorphometric Analysis}

Comparative histomorphometric determinations and significance levels are shown in Table 1 and represented in Figure 5. After 10 weeks, ABB and MSi implanted cylinders achieved similar and the highest $\%$ of occupied space values. MSi also presented the highest $\%$ of new Bone and the lowest $\%$ of non-osteointegrated material values.

\subsubsection{ABB Granulates}

The ABB group $(n=7)$ remained almost full and filled over 90 vol\%. New bone was observed to vertically grow up to $55 \mathrm{vol} \%$ of the cylinder height. The area of the newly formed bone was $23.6 \pm 7.3 \%$. Osteointegrated ABB granules occupied $22 \pm 10 \%$ of the cylinder area, whereas $9.2 \pm 5.8 \%$ of the region remained with non-osteointegrated particles (Table 1 and Figure 5).

ABB showed a characteristic pattern of scarce new trabecular bone formed surrounding granules, which mainly appeared osteointegrated (Figure 6a-f). Due to the notable presence of $\mathrm{ABB}$ granules and its osteointegration, the new trabecular bone was formed in a thin, irregular and disorganized way and acquired the same sharp morphology as the granules. (Figure $6 \mathrm{~b}, \mathrm{c}, \mathrm{f})$. In the bone marrow spaces, adipose and predominating hematopoietic bone marrow were present (Figure $6 \mathrm{~b}, \mathrm{c}$ ). Mature osteocytes were present in newly formed bone (Figure $6 \mathrm{c}, \mathrm{f})$. ABB granules did not show significant morphological changes after implantation (Figure $6 \mathrm{~b}, \mathrm{c}, \mathrm{e}, \mathrm{f}$ ), and no signs of vascular or tissue invasion inside ABB granules were evident (Figure 6c,e,f). Non-integrated granules, presented at the cylinder upper part, appeared surrounded by connective tissue with no signs of invasion within granules (Figure 6a). The border between integrated and non-integrated material show continuity between newly formed bone and connective tissue surrounding the non-integrated granules (Figure 6a). 


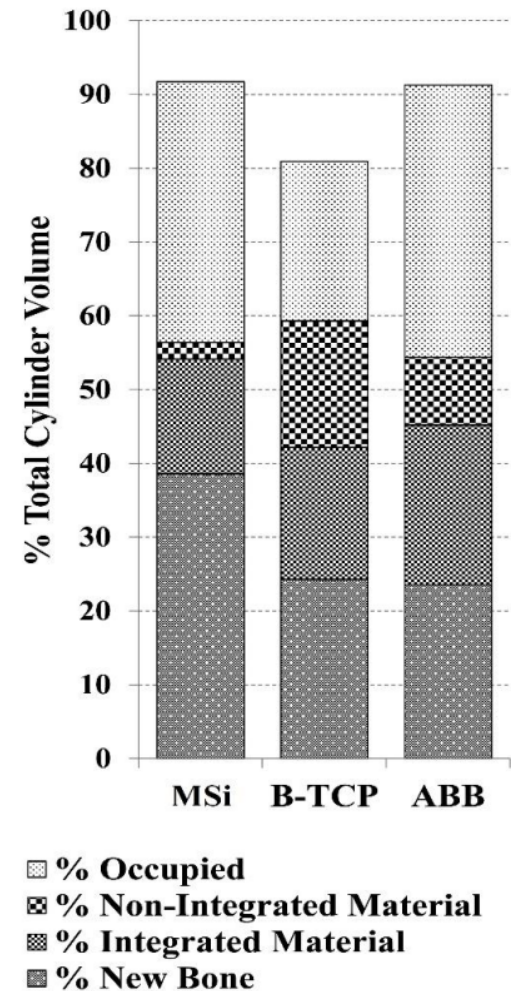

Figure 5. Graphical representation of the histomorphometric determinations for: $\mathrm{ABB}, \beta-\mathrm{TCP}$ and MSi.
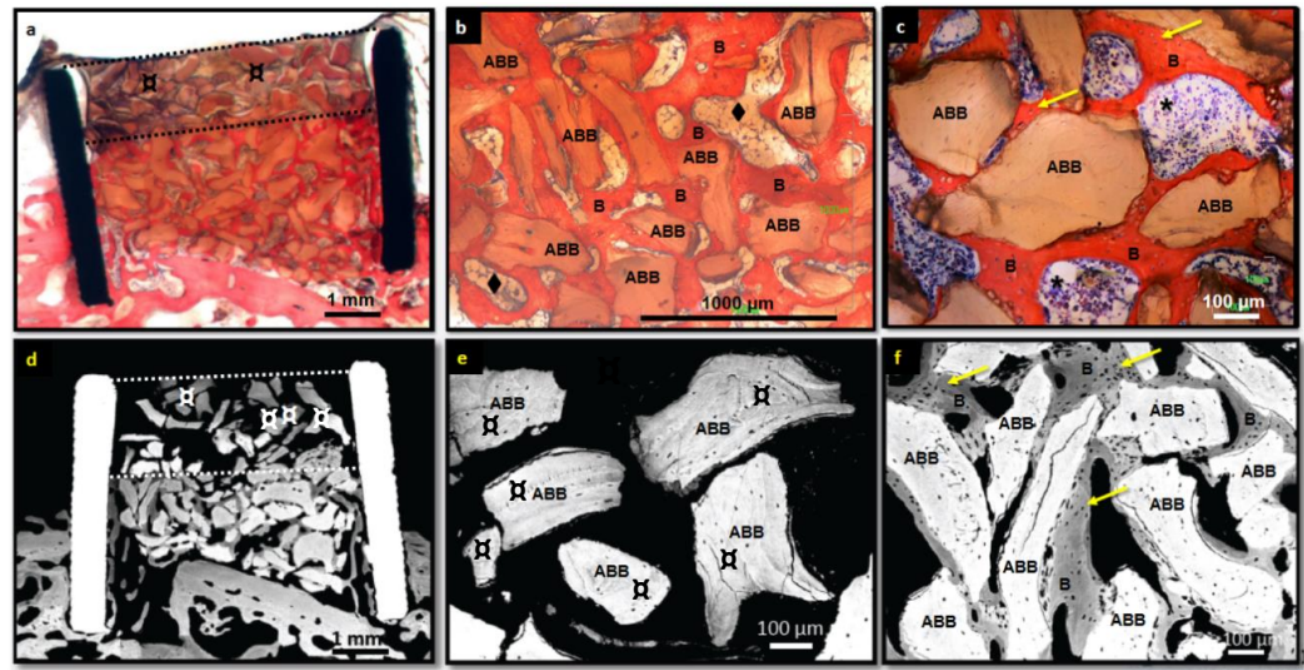

Figure 6. Histological (a-c) and BS-SEM images (d-f) of rings implanted with ABB granules. Rings remained almost full to the top of the cylinder (upper dotted line) with notable remaining granules of $\mathrm{ABB}(\mathbf{a}, \mathbf{d})$. Non-osteointegrated granules were surrounded by connective tissue at the upper part of the cylinder $(\mathbf{a}, \mathbf{d}, \mathbf{e})$. Vertical bone growth achieved the middle of the cylinder height (lower dotted line) (a,d). A very well osteointegrated particles surrounded by new bone were observed in all images, except e, which showed non-osteointegrated material present at the upper part of the cylinder. No changes in particle morphology after implantation were observed $(\mathbf{b}, \mathbf{c}, \mathbf{e}, \mathbf{f})$. Mature osteocytes were present at the newly formed bone $(\mathbf{c}, \mathbf{f})$. (Legend: B: newly formed bone; $\mathbf{a}$ : nonosteointegrated granules; *: hematopoietic bone marrow; : adipose bone marrow; yellow arrows: osteocytes lacunae). 
A homogeneous "activation" of calvaria bone was not possible during surgeries. This activation was intended to remove part of the outer cortical calvaria bone to encourage bleeding and the contact of biomaterials to the bloody bone. In the ABB group, calvaria bone was quite preserved in four implants, whereas it was greatly removed in the rest. Bone growth in the implants where the cortical bone was major conserved was $26 \pm 6 \%$ and where calvaria was greatly removed $20 \pm 8 \%(\alpha \leq 0.05)$. Therefore, conservation of the calvaria bone did not influence bone growth in the ABB group.

\subsection{3. $\beta$-TCP Granulates}

Cylinders implanted with $\beta$-TCP maintained volume only up to $80 \%$, the remaining $20 \%$ of the cylinder was empty after the study period (Figure $7 \mathrm{a}, \mathrm{d}$ ). In no case did the bone grow to the top of the cylinder or up to the occupied area but only to $41 \%$ of the cylinder height. The extent of new bone was $24 \pm 15 \%$. Osteointegrated $\beta$-TCP granules comprised $18 \pm 12 \%$ of the cylinder area, and a high area remained occupied by non-osteointegrated $\beta$-TCP particles, whose size decreased considerably (Table 1 and Figure 5).
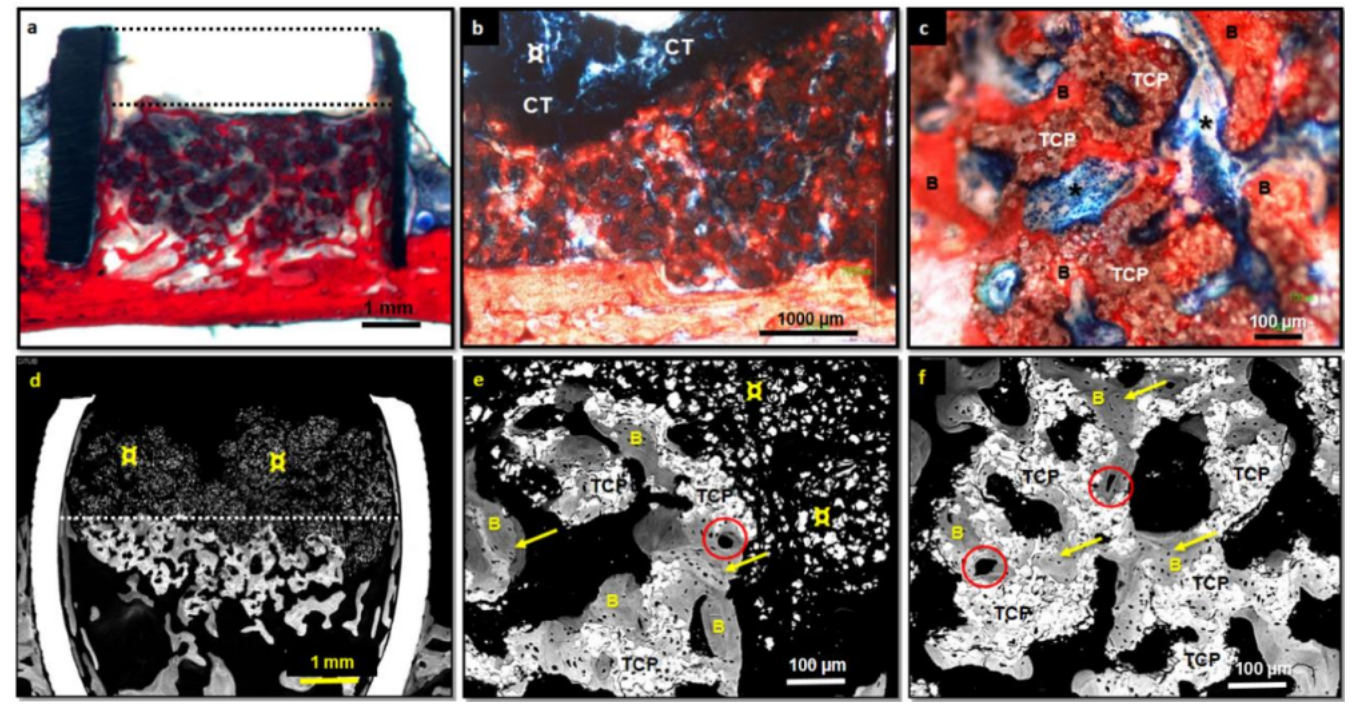

Figure 7. Histological $(\mathbf{a}-\mathbf{c})$ and BS-BSE images $(\mathbf{d}-\mathbf{f})$ of rings implanted with $\beta$-TCP granules. After implantation, $20 \%$ of the cylinder was empty (upper dotted line) (a). A high amount of remaining $\beta$-TCP was not osteointegrated $(\mathbf{b}, \mathbf{d}, \mathbf{e})$ and vertical bone growth achieved only the middle of the cylinder height (lower dotted line) (a,d). Non-osteointegrated granulates were surrounded by connective tissue at the upper cylinder part (b). New trabecular formed bone showed homogeneous material osteointegration (b,c,e,f). Trabecular bone maturation was evident, with regular mineralized osteocytes lacunae and some vascular channels $(\mathbf{e}, \mathbf{f})$. Hematopoietic bone marrow was present (c). Legend: B: newly formed bone; $a$ : non-osteointegrated material; *: hematopoietic bone marrow; yellow arrow: osteocytes lacunae; red circle: vascular channels; CT: connective tissue; TCP: $\beta$-TCP material.

Significantly, the regeneration of implants containing $\beta$-TCP $(n=8)$ was heterogeneous, as can be inferred from the wide standard deviation of the parameters of the histomorphometric study.

In the $\beta$-TCP group, trabecular bone formation mainly occurred near the calvarial zone (Figure 7), where the $\beta$-TCP particles are homogeneously osteointegrated (Figure $7 \mathrm{~b}, \mathrm{c}, \mathrm{e}, \mathrm{f}$ ). The newly formed bone presented a characteristic pattern with very thin trabeculae where the disintegrated particles interrupted their continuity (Figure 7c,e,f). The formed trabecular bone was mature, showing regular lacunae of mineralized osteocytes and some vascular channels (Figure 7e,f). Hematopoietic bone marrow was also observed (c). Large numbers of non-osteointegrated particles surrounded by connective tissue were observed (Figure $7 \mathrm{~b}$ ). 
The transformation of the $\beta$-TCP granules was significant, from an initial size between 500 and $1000 \mu \mathrm{m}$ to much smaller particle aggregates with diameters between 10-20 $\mu \mathrm{m}$ (Figure 7c,e,f).

Regarding the influence of the state of calvaria conservation in bone formation when $\beta$-TCP was implanted, cortical bone remained almost intact in three implants; in another case, only a small part of the cortical bone was removed. In the other four implants, most of the cortical were eliminated. In the first cases, scarce bone growth occurred $(11 \pm 9 \%)$, and a notable amount of non-osteointegrated material was observed. In the second case, $25 \%$ of bone was formed. The last group showed the highest bone growth $(27 \pm 11 \%)(\alpha \leq 0.05)$. Therefore, decortication of the calvaria bone influenced bone formation in the $\beta$-TCP group.

\subsubsection{MSi Granulates}

The MSi group $(n=7)$ remained filled over 91\%. New trabecular formed bone was observed to vertically grow up to $58 \mathrm{vol} \%$ of the cylinder height. MSi implants were characterized by high bone growth ( $39 \pm 14 \%)$, the highest of the three studied materials, where the bone grows through the whole cylinder volume where particles were present. MSi osteointegrated particles were $15.6 \pm 7.5 \%$ and non-osteointegrated $2.2 \pm 5.6 \%$, being the lower value of residual material of the studied granules (Table 1 and Figure 5).

MSi implants showed new trabecular bone, with well osteointegrated material and occupying almost the top of the cylinder (Figure 8a-f). New trabecular bone presented wide trabeculae with numerous vascular cavities and high osteogenic activity (Figure $8 \mathrm{~b}, \mathrm{e})$. These 30-50 $\mu \mathrm{m}$ of diameter vascular channels were observed indistinctly inside the bone and in osteointegrated MSi particles (Figure 8b,c,e,f). MSi osteointegrated particles presented bone formation and cell bone colonization inside them (Figure 8c). A close relation between regenerated bone and osteointegrated MSi particles (Figure 8b,c,d,e) was evident, indicating their high osteoconduction and capacity to promote bone formation and maturation.
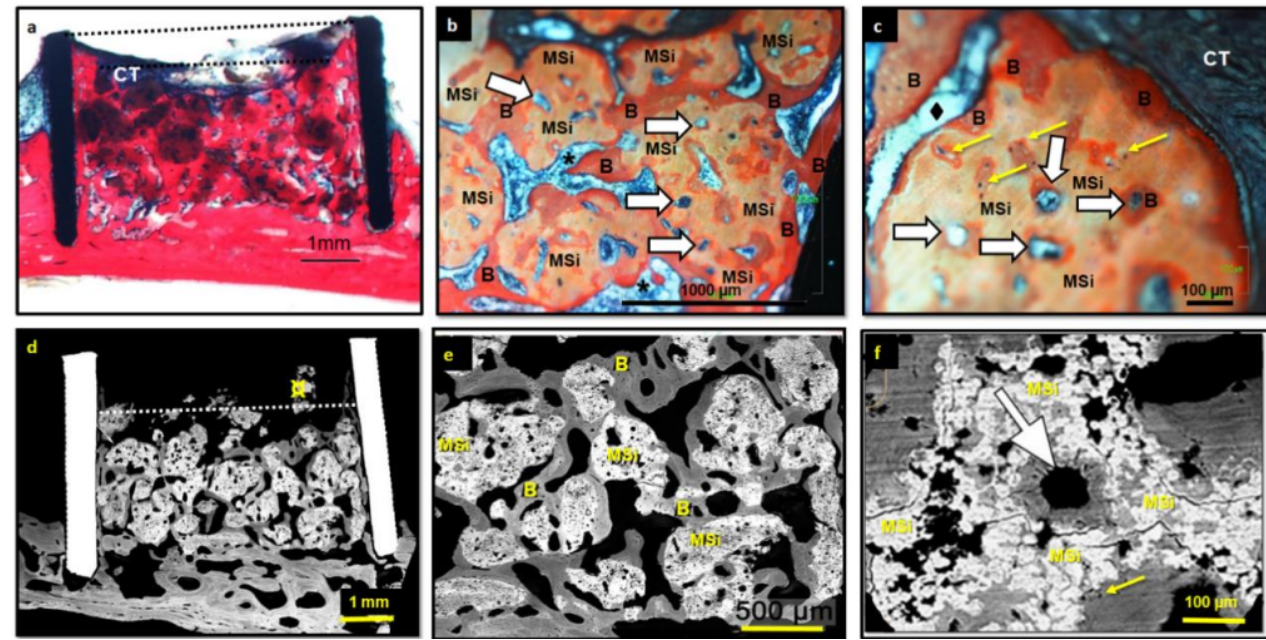

Figure 8. Histological $(\mathbf{a}-\mathbf{c})$ and BS-BSE images $(\mathbf{d}-\mathbf{f})$ of rings implanted with MSi. The volume of the cylinder remained almost completed filled (upper dotted line). The regenerated bone occupied the cylinder almost completely (lower dotted line) (a). The remaining particles were perfectly osteointegrated in a new trabecular bone (a-f). Granules became more porous and with a bigger pore size $(\mathbf{a}-\mathbf{f})$. New trabecular bone maturation was evident, with regular mineralized osteocytes lacunae and numerous vascular channels $(\mathbf{b}, \mathbf{c}, \mathbf{f})$. Numerous vascular cavities were observed within osteointegrated MSi particles (c,f). Newly mineralized and cellularized bone was formed inside osteointegrated material granules $(\mathbf{c}, \mathbf{f})$. Both hematopoietic and adipose bone marrow were evident $(\mathbf{b}, \mathbf{c})$. Connective tissue was surrounded the scarce non-osteointegrated granulates at the top of the cylinder (a). (Legend: B: newly formed bone; a: non-osteointegrated material; ${ }^{*}$ : hematopoietic bone marrow; : adipose bone marrow; yellow arrow: osteocytes lacunae; white arrow: vascular channels; CT: connective tissue). 
It should also be remarked that non-osteointegrated MSi particles showed bone formation inside them and on the surface that was in contact with connective tissue (Figure 8c). New trabecular bone showed osteocytes and notable vascular cavities (Figure 8b,c,f). Moreover, the development of both adipose and hematopoietic bone marrow was observed, a sign of bone maturation (Figure $8 b, c$ ).

MSi particles were reabsorbed both from the surface and the inside, increasing the porosity of material over time. These spaces have been penetrated by vascularized channels promoting new bone formation.

Concerning the conservation of calvaria bone in MSi implants, it was well preserved in five cases which showed $34 \pm 13 \%$ of newly formed bone. In the other two MSi implants, cortical bone was almost eliminated and showed $37 \pm 7 \%$ of new bone $(\alpha \leq 0.05)$. Therefore, differences in the calvaria bone maintenance appeared not to influence bone growth in the MSi group, as has been observed in the ABB group.

\section{Discussion}

The present study compared the capacity of vertical bone regeneration of two established bone graph materials, ABB and $\beta-\mathrm{TCP}$, with a novel synthetic nanostructured material composed of Zn-substituted monetite, amorphous calcium phosphate, hydroxyapatite and hydrated silica gel.

In oral surgery, bone regeneration procedures are often followed by endosseous implants. After the primary mechanical engagement, implant stability is highly dependent on the osteointegration achieved with bone regeneration and bone remodeling around the implant. Implant stability is the main parameter that determines implant loading schedule and treatment outcome [40-44].

The ideal bone graft to achieve vertical bone augmentation should be osteoconductive, i.e., act as three-dimensional support to guide bone growth, induce bone growth (osteoinductive) and be gradually resorbed and simultaneously replaced by newly formed bone [45-48]. The ultimate goal is to increase the necessary bone volume in the shortest possible time and completely replace the initial bone material with quality mature bone.

Vertical bone augmentation in rabbit calvaria is an established model for evaluating bone regeneration materials. The calvarial bone is ideal for vertical bone augmentation because of its embryological, morphological, and physiological similarities with the oral and maxillofacial region [49-51]. Besides, it has a large flat surface, facilitating the fixation of titanium rings [52].

One of the challenges of this model is that the graft material does not come out, so closed dome-shaped containers have been used [53]. In this case, the result may be affected by the osteoconductive effect of the chamber. To avoid this, a lid has been used instead of a closed chamber [54]. In the present study, the top of the cylinder was left open to make the model as similar as possible to medical applications, where part of the bone defect may be exposed to surrounding tissues or covered by a resorbable membrane.

Regarding methods used for histomorphometric analysis, micro-CAT scans provided a solid estimate of the radiopaque area, which was $90 \%$ for $\mathrm{MSi}, 89 \%$ for $\mathrm{ABB}$ and $80 \%$ for $\beta$-TCP. However, this technique could not discern between newly formed bone and residual material. Therefore, quantification of the other parameters was based on histology sections. Histomorphometric analysis coincided with the average estimations of the radiopaque area observed by micro-CAT scans.

In the histomorphometric evaluation of this work, \%New Bone was restricted to areas within the cylinders that stained in red, by Van Gieson picrofucsine, excluding areas occupied by Residual Material and Connective Tissue. Although this criterion differs from some previous reports, where the Integrated Material was incorporated into the $\% \mathrm{New}$ Bone value [55]. we consider it appropriate for a better-studied materials differentiation, considering their different resorption profiles.

Control materials, $\mathrm{ABB}$ and $\beta$-TCP, have an opposite in vivo behavior mostly due to their different composition and physical properties, such as porosity and surface specific 
area. ABB was considered as a control for a stable and no reabsorbable material. On the other hand, $\beta$-TCP was studied as an example of a resorbable material. Thus, we expected MSi might have an intermediate resorbable behavior compared to both controls (ABB and $\beta$-TCP).

Histological evaluation showed ABB implants were almost completely full, where material particles occupied almost the maxima height of the cylinder. New bone grew around particles, which presented good osteoconductive properties and osteointegration within the new bone formed. ABB could be considered as a stable material, with no sign of morphological changes over the implantation period, remaining practically unaltered. Almost 30\% of the cylinder area remained occupied by ABB granules $(21 \pm 10 \%$ osteointegrated and $9 \pm 6 \%$ non-osteointegrated, respectively). Present observations confirmed previous reports where ABB granules behave as osteoconductive scaffolds surrounded by fibrous connective tissue and replaced by new bone, with no invasion by connective tissue, no resorption nor cell colonization inside the granules $[19,56]$. This is supported by the fact that $A B B$ granules are mostly insoluble and have intra-particle pores below $0.2 \mu \mathrm{m}$, averaging $0.03 \mu \mathrm{m}$ [57], which are three orders of magnitude smaller than the $100 \mu \mathrm{m}$ generally considered a requirement for cell colonization. [58]. This behavior was supported by the porosity measurements obtained in this work. Two different porosity morphologies were characterized: around $(1.6 \mu \mathrm{m}$ of diameter) and elongated (average size of $6 \mu \mathrm{m}$ long and $0.34 \mu \mathrm{m}$ high). Furthermore, mercury porosimetry results revealed the small size of interconnections between pores (from 200 to $7 \mathrm{~nm}$ ). Although isolate macropores (20-130 $\mu \mathrm{m})$ were observed by SEM, the average was $50 \mu \mathrm{m}$, so the requirement for cell colonization was not possible.

Concerning $\beta$-TCP, a synthetic pure-phase (>99\%) used as control, its in vivo resorbable behavior was opposite to ABB. $\beta$-TCP granules changed their initial morphology from 500-1000 $\mu \mathrm{m}$ to particle agglomerates of very small size (around $15 \mu \mathrm{m}$ ) as a result of the dissolution of the contact points of sintered particles. Although both materials had opposite resorption, both showed similar bone formation: $\beta$-TCP $(24 \pm 15 \%)$ and ABB (24 $\pm 7 \%)$. $\beta$-TCP cylinder occupied area was the lowest $(81 \pm 9 \%)$ being the difference with ABB $(91 \pm 13 \%)$ and MSi $(92 \pm 3 \%)$ significant $(\alpha \leq 0.05)$. This may be due to early resorption, not fulfilling the clinical requirements to space-maintenance function. $\beta$-TCP histological images confirmed that particles were osteointegrated after 10 weeks. In previous work, a small size of TCP granules (nanometers scale) induced higher porosity and larger specific surfaces, leading to an improved regenerative effect [59]. Previous comparative histology reports of implanted $\beta$-TCP granules showed they were resorbable and promoted new bone formation [60-62].

Nanostructured MSi studied material is composed of monetite, in which calcium was partially substituted by Zn, hydroxyapatite, amorphous calcium phosphate and silica gel. The experimental research was focused on a different approach to accelerate bone regeneration. The rationale behind MSi material composition was to provide a material capable of acting as a three-dimensional scaffold also accelerating bone formation by releasing ionic species, such as $\mathrm{Ca}, \mathrm{P}, \mathrm{Si}$ and $\mathrm{Zn}$ [25-27]. Thus, the main component, monetite, was chosen due to their higher resorption combined with amorphous calcium phosphate and hydroxyapatite with a slower resorption rate [26].

MSi implants' in vivo behavior were characterized by a remarkable bone growth (38\%), practically full-occupied cylinder area (91\%) and most of the particles osteointegrated, being only $2 \%$ of the cylinder occupied by non-osteointegrated granules. The histomorphometric evaluation showed a significantly greater new bone for MSi $(39 \pm 14 \%)$ than for $\beta$-TCP $(24 \pm 15 \%)$ or ABB ( $24 \pm 7 \%)$. The occupied space was very similar for ABB and MSi, but both were significantly different with the $\beta$-TCP group. Remarkable resorption promoting the bone formation of MSi was evidenced after 10 weeks of implantation.

Both histology and BS-SEM images revealed, unlike the controls, that MSi granules appeared mostly osteointegrated, with evident signs of cell colonization and new bone formation inside the particles. The release of $\mathrm{Ca}, \mathrm{Si}, \mathrm{P}$ and $\mathrm{Zn}$ ions to the environment $[26,27]$, 
promote the formation of an apatite surface layer which is generally associated with improved osteointegration surface [63,64].

The initial intra-granular pore sizes of MSi $(3.5-0.15 \mu \mathrm{m})$ are not large enough for cell colonization but allow the diffusion of the released species, favor the entry of proteins and nutrients and the reabsorption of granules. The biomaterial resorption provided larger pores adequate for neovascularization, followed by cell colonization. This process is essential to bone regeneration $[38,65]$.

MSi is a nanostructured material, the same as bone apatite. Nanometric calcium phosphates have shown enhanced osteoblast adhesion, proliferation and mineralization compared with microstructured materials leading to increased formation of new bone tissue within a short period [66,67]. This is an important feature over microstructured materials, as nanometric morphology contributes to increased reactivity of the material, improved protein adsorption and interaction with osteoblasts, as well as facilitating bio-material passive and active resorption by osteoclast and macrophage activity [26,66-70].

In addition to composition and morphology, the biomaterial also showed relevant features that contribute to their biological performance as bone regeneration material, such as high interconnected porosity, specific surface area and surface roughness. These advantageous physical properties are related to the synthesis method which involves a hydraulic cementing reaction in which material consolidation is achieved through a low temperature dissolution-precipitation process, giving rise to hydrated compounds with morphologies and compositions very similar to the calcium phosphates found in the mineralized tissues, high specific surface area, porosity, surface roughness and nanostructure [26,27].

Monetite, a major component of MSi, has been previously reported as resorbable material that is gradually replaced by new bone, that grows inside and around grafted granules in the bone regeneration model in rabbit calvaria [71] or in alveolar bone human defects [72]. The presence of silicon in MSi could contribute to the initiation of calcified tissue mineralization [73]. Recent studies suggested that silicon has a dual nature in bone metabolism, with stimulatory effects on osteoblasts and inhibitory effects on osteoclasts [74]. Furthermore, MSi is also composed of zinc, which has been reported to contribute to the resorption of other calcium phosphates, such as $\beta-\mathrm{TCP} 35$ ] and may also play an important role in the resorption of MSi. However, as for $\beta$-TCP, bovine HA or BCP (Biphasic calcium phosphate) the influence of material dissolution processes and osteoclast involvement remain unclear [75]. Our results showed that the calcified tissues studied at 10 weeks post-implantation, were more mature and structured in wider trabeculae in MSi group compared to the other materials. Furthermore, the remaining MSi particles showed several areas of neovascularization and new bone formation inside the particles, being a sign of a process of substitution of biomaterial by bone.

Regardless of the results obtained in this work, in other studies where ABB was grafted in titanium cylinders ( $9 \mathrm{~mm}$ of diameter) in rabbit calvaria for 4 weeks, bone volume was similar 13 [76] and $11 \%$ [19] respectively. However, in our work, ABB new bone was higher $(23 \%)$, but a long period was evaluated (10 weeks) of bone formation over time. Related to the remaining ABB graft, similar values were obtained 35 [77] vs. $30 \%$ (21\% osteointegrated $+9 \%$ non-osteointegrated) in our work, showing no resorption of ABB granules from 4 to 10 weeks of study. In other similar work [56], where titanium cylinders covered by a lid were studied for 12 weeks, ABB occupied cylinder volume was $94 \%$ vs. $91 \%$ obtained in the present study. Additionally, in other work using a closed cylinder $(6 \mathrm{~mm}$ diameter and $1 \mathrm{~mm}$ height) at 6 weeks, bone values for BCP (Biphasic calcium phosphate HA/TCP) were slightly higher than for ABB ( 35 and $25 \%$ respectively) [77]. Bio-Oss ${ }^{\circledR}$ new bone value was similar to our results (23\%). In other work, where a granulated brushite-TCP cement was studied at 4 weeks [78], bone regeneration was $16 \%$ vs. $38 \%$ obtained for our MSi studied material. Besides, in a previous work, where a 3D $\alpha$-TCP/HA material was studied compared to ABB and $\beta$-TCP in titanium cups at sheep calvaria at 8 and 16 weeks [79], new bone values at 8 weeks were lower (ABB 13\%, $\beta$-TCP $13 \%$ and $\alpha$-TCP $/ \mathrm{HA}$ $23 \%$ ) than compared to the obtained is our work (ABB 23\%, $\beta$-TCP $24 \%$ and MSi $39 \%$ ). At 
16 weeks new bone occupied about $40 \%$ of the volume under the titanium hemispheres in the three tested materials [79], with the value being very similar to MSi (39\%) in our work at 10 weeks. It should be considered that in our study open titanium cylinders were used, so the exposure to biological fluids was higher. In relation to degradation, the volume of the remaining material for ABB and $\alpha$-TCP/HA were the same for 8 and 16 weeks (40 and $45 \%$ respectively) [79], mostly due to the presence of HA on their chemical composition. In our work, the remaining $\mathrm{ABB}$ was quite similar $(31 \%)$. $\beta$-TCP remained material was $33 \%$ at 8 weeks [79], similar to $\beta$-TCP (34\%) in our work, whereas for our studied material MSi was 17\%, highlighting its higher resorption. In previous work, 3D printed monolithic monetite blocks were also studied in calvaria rabbits at 8 weeks [13]. Monetite blocks new bone was $43 \%$, similar to MSi (39\%) in our work. Dental implants can be successfully placed into regenerated bone with a bone volume of 30-40\% [80]. There are several studies where bone augmentation procedures with dental implants have been stabilized with this amount of bone volume [81,82].

In the experimental model used in this work, the importance of decortication or cortical bone perforations is somewhat the subject of some controversy. Some reports supported that cortical preservation compromised results, leading to increased bone augmentation $[83,84]$. However, other authors concluded that the cortical bone plate was compromised at the site of the titanium cylinder and there may be sufficient damage to see no difference between the corticated and decorticated experimental setups [54]. This work selected decortication based on the typical clinical scenario where graft materials are implanted directly with bleeding bone. However, as explained before, decortication was not homogeneous in all samples, and it appeared to influence only the bone formation of the $\beta$-TCP group. Therefore, we suggested that the composition and physicochemical properties of the materials influence vertical growth more than the state of the calvaria bone. Thus, ABB and MSi materials could be considered to have a good osteoconductive capacity even if the calvaria bone has been preserved. However, $\beta$-TCP osteoconductive capacity was not good enough and needed to have an active bleeding bone to promote bone formation.

This study is limited to a small space, using titanium cylinders in rabbit calota, which is not representative of clinical practice. Therefore, the vertical bone augmentation capacity of this material needs to be further evaluated in clinical settings. Additional studies are also needed to investigate the osseointegration and stability of the endosseous implant when MSi is used.

Resorbable graft materials, such as MSi may increase implant stability by facilitating biological processes associated with bone remodeling during the bone regeneration period and promoting dense bone formation in the vicinity of the endosseous implant [85], avoiding interference of residual graft material.

\section{Conclusions}

The three evaluated materials were capable of vertical bone augmentation but with a very different behavior highly conditioned by their different composition, solubility, morphology, specific surface area, porosity and pore size distribution, and granular cohesion.

ABB maintained a high volume of the defect filled as it remains in the site without resorption. It shows a good osteoconductive behavior related to its high specific surface area and porosity in the micro and nanometric range.

$\beta$-TCP lost its granular structure and appeared disintegrated in small particles $(15 \mu \mathrm{m})$ because of the reabsorption of the neck union between grains. In addition, the specific surface area of this material is extremely low, with no porosity inside the grains as characteristic of sintered materials. All these factors were detrimental for supporting bone growth and, therefore, volume preservation showing a significant lowest volume augmentation and a higher amount of non-osteointegrated material.

On the contrary, MSi showed the best bone regeneration and vertical augmentation performance. It achieved the highest amount of new bone, the lowest amount of connective 
tissue and almost all the remaining particles osseointegrated. New trabecular bone was mature, vascularized with high osteogenic activity formed by broad trabeculae.

MSi showed clear signs of resorption, bone ingrowth, cellular colonization and several vascular cavities outside and inside granules, being the remaining particles perfectly osseointegrated.

The very scarce MSi particles non-osteointegrated surrounded by connective tissue also showed bone formation and vascularization inside granulates and around it, indicating that material induces bone formation, i.e., osteoinductive.

MSi is a nanostructured multicomponent material, whose components have different reabsorption rate that gradually resorbs, and simultaneously releases ionic species that favor bone regeneration, such as $\mathrm{Zn}, \mathrm{Si}, \mathrm{Ca}$ and phosphate ions. The excellent biological behavior of this material is also related to its high specific surface area high roughness, high interconnected porosity with pores ranging from macro to nanopores, good granular cohesion, homogeneous and intimate distribution of its components and nanometric structure similar to bone apatite.

Decortication of the calvaria bone influenced bone formation in the $\beta$-TCP group, but not in $\mathrm{ABB}$ and MSi implants, indicating better osteoconductive behavior of the latter compared to $\beta$-TCP.

Author Contributions: Conceptualization, L.B.-G., A.G.d.C. and S.P.; Methodology, L.B.-G., and S.P.; Validation, L.B.-G., M.-C.M. and S.P.; Formal Analysis, L.B.-G., Y.G., I.V.-G. and S.P.; Investigation, L.B.-G., Y.G., I.D.-G., I.V.-G., M.-C.M. and S.P.; Writing-Original Draft Preparation, L.B.-G. and Y.G.; Writing-Review \& Editing, S.P.; Supervision, S.P.; Project Administration, A.G.d.C. and S.P.; Funding Acquisition, A.G.d.C. and S.P. All authors have read and agreed to the published version of the manuscript.

Funding: This research was funded by Programa Nacional INNPACTO (ECC/1345/2012) (IPT-20120560-010000) and Subprograma RETOS-COLABORACIÓN (RTC-2014-1731-1).

Institutional Review Board Statement: The study was conducted according to the guidelines of the Declaration of Helsinki, and approved by the Ethics Committee of the Centro de Cirugía Mínima Invasiva Jesús Usón (protocol code 035/11, 20/11/2011).

Data Availability Statement: The data is included in the main text.

Acknowledgments: Programa Nacional de Cooperación Público-Privada-Subprograma INNPACTO (ECC/1345/2012) del Ministerio de Economía y Competitividad, España (Spain),(IPT-2012-0560010000) "Sil-Oss: Osteoinductive biomaterial for bone regeneration" and Subprograma RETOSCOLABORACIÓN, (RTC-2014-1731-1) “Evaluación de Compatibilidad de SIL-OSS con Implantes Intraóseos y otras aplicaciones en Odontología". The authors wish to thank also to Silvia Enciso of Centro de Cirugía de Mínima Investigación Jesús Usón (Spain) for the assistance in the surgeries.

Conflicts of Interest: The authors declare no conflict of interest.

\section{References}

1. Huumonen, S.; Haikola, B.; Oikarinen, K.; Söderholm, A.-L.; Remes-Lyly, T.; Sipilä, K. Residual ridge resorption, lower denture stability and subjective complaints among edentulous individuals. J. Oral Rehabil. 2012, 39, 384-390. [CrossRef] [PubMed]

2. Bernstein, S.; Cooke, J.; Fotek, P.; Wang, H.-L. Vertical Bone Augmentation: Where Are We Now? Implant. Dent. 2006, 15, 219-228. [CrossRef] [PubMed]

3. Chiapasco, M.; Zaniboni, M. Methods to Treat the Edentulous Posterior Maxilla: Implants With Sinus Grafting. J. Oral Maxillofac. Surg. 2009, 67, 867-871. [CrossRef]

4. Rocchietta, I.; Fontana, F.; Simion, M. Clinical outcomes of vertical bone augmentation to enable dental implant placement: A systematic review. J. Clin. Periodontol. 2008, 35, 203-215. [CrossRef]

5. Felice, P.; Marchetti, C.; Iezzi, G.; Piattelli, A.; Worthington, H.; Pellegrino, G.; Esposito, M. Vertical ridge augmentation of the atrophic posterior mandible with interpositional bloc grafts: Bone from the iliac crest vs. bovine anorganic bone. Clinical and histological results up to one year after loading from a randomized-controlled clinical trial. Clin. Oral Implant. Res. 2009, 20, 1386-1393. [CrossRef]

6. Kumar, G.; Narayan, B. Morbidity at Bone Graft Donor Sites. In Classic Papers in Orthopaedics; Banaszkiewicz, P.A., Kader, D.F., Eds.; Springer: London, UK, 2014; pp. 503-505. 
7. Goulet, J.A.; Senunas, L.E.; DeSilva, G.L.; Greenfield, M.L.V.H. Autogenous Iliac Crest Bone Graft: Complications and Functional Assessment. Clin. Orthop. Relat. Res. 1997, 339, 76-81. [CrossRef] [PubMed]

8. Orsini, G.; Bianchi, A.E.; Vinci, R.; Piattelli, A. Histologic evaluation of autogenous calvarial bone in maxillary onlay bone grafts: A report of 2 cases. Int. J. Oral Maxillofac. Implant. 2003, 18, 594-598.

9. Simion, M.; Jovanovic, S.A.; Tinti, C.; Benfenati, S.P. Long-term evaluation of osseointegrated implants inserted at the time or after vertical ridge augmentation. Clin. Oral Implant. Res. 2001, 12, 35-45. [CrossRef]

10. Araújo, M.G.; Sonohara, M.; Hayacibara, R.; Cardaropoli, G.; Lindhe, J. Lateral ridge augmentation by the use of grafts comprised of autologous bone or a biomaterial. An experiment in the dog. J. Clin. Periodontol. 2002, 29, 1122-1131. [CrossRef]

11. Friedmann, A.; Dard, M.; Kleber, B.-M.; Bernimoulin, J.-P.; Bosshardt, D.D. Ridge augmentation and maxillary sinus grafting with a biphasic calcium phosphate: Histologic and histomorphometric observations. Clin. Oral Implant. Res. 2009, 20, 708-714. [CrossRef]

12. Rothamel, D.; Schwarz, F.; Herten, M.; Ferrari, D.; Mischkowski, R.A.; Sager, M.; Becker, J. Vertical ridge augmentation using xenogenous bone blocks: A histomorphometric study in dogs. Int. J. Oral Maxillofac. Implant. 2009, 24, $243-250$.

13. Tamimi, F.; Torres, J.; Gbureck, U.; Lopez-Cabarcos, E.; Bassett, D.; Alkhraisat, M.; Barralet, J.E. Craniofacial vertical bone augmentation: A comparison between 3D printed monolithic monetite blocks and autologous onlay grafts in the rabbit. Biomaterials 2009, 30, 6318-6326. [CrossRef]

14. Torres, J.; Tamimi, F.; Alkhraisat, M.H.; Prados-Frutos, J.C.; Rastikerdar, E.; Gbureck, U.; Barralet, J.E.; López-Cabarcos, E. Vertical bone augmentation with 3D-synthetic monetite blocks in the rabbit calvaria. J. Clin. Periodontol. 2011, 38, 1147-1153. [CrossRef]

15. Wang, X.; Zakaria, O.; Madi, M.; Hao, J.; Chou, J.; Kasugai, S. Vertical bone augmentation induced by ultrathin hydroxyapatite sputtered coated mini titanium implants in a rabbit calvaria model. J. Biomed. Mater. Res. Part B Appl. Biomater. 2014, 103, 1700-1708. [CrossRef]

16. Namli, H.; Erdogan, Ö.; Gönlüşen, G.; Kahraman, O.E.; Aydin, H.M.; Karabag, S.; Tatli, U. Vertical Bone Augmentation Using Bone Marrow-Derived Stem Cells. Implant. Dent. 2016, 25, 54-62. [CrossRef]

17. Hämmerle, C.H.F.; Olah, A.J.; Schmid, J.; Fl“"ckiger, L.; Gogolewski, S.; Winkler, J.R.; Lang, N.P. The biological effect of natural bone mineral on bone neoformation on the rabbit skull. Clin. Oral Implant. Res. 1997, 8, 198-207. [CrossRef]

18. Skoglund, A.; Hising, P.; Young, C. A clinical and histologic examination in humans of the osseous response to implanted natural bone mineral. Int. J. Oral Maxillofac. Implant. 1997, 12, 1-12.

19. Tamimi, F.M.; Torres, J.; Tresguerres, I.; Clemente, C.; López-Cabarcos, E.; Blanco, L.J. Bone augmentation in rabbit calvariae: Comparative study between Bio-Oss ${ }^{\circledR}$ and a novel $\beta$-TCP/DCPD granulate. J. Clin. Periodontol. 2006, 33, 922-928. [CrossRef]

20. Cordaro, L.; Bosshardt, D.D.; Palattella, P.; Rao, W.; Serino, G.; Chiapasco, M. Maxillary sinus grafting with Bio-Oss ${ }^{\circledR}$ or Straumann ${ }^{\circledR}$ Bone Ceramic: Histomorphometric results from a randomized controlled multicenter clinical trial. Clin. Oral Implant. Res. 2008, 19, 796-803. [CrossRef]

21. De Santis, E.; Lang, N.P.; Scala, A.; Viganò, P.; Salata, L.A.; Botticelli, D. Healing outcomes at implants installed in grafted sites: An experimental study in dogs. Clin. Oral Implant. Res. 2011, 23, 340-350. [CrossRef]

22. Lieberman, I.H.; Togawa, D.; Kayanja, M.M. Vertebroplasty and kyphoplasty: Filler materials. Spine J. 2005, 5, S305-S316. [CrossRef]

23. Pripatnanont, P.; Praserttham, P.; Suttapreyasri, S.; Leepong, N.; Monmaturapoj, N. Bone Regeneration Potential of Biphasic Nanocalcium Phosphate with High Hydroxyapatite/Tricalcium Phosphate Ratios in Rabbit Calvarial Defects. Int. J. Oral Maxillofac. Implant. 2016, 31, 294-303. [CrossRef]

24. Gerhardt, L.-C.; Boccaccini, A.R. Bioactive Glass and Glass-Ceramic Scaffolds for Bone Tissue Engineering. Materials 2010, 3 , 3867-3910. [CrossRef]

25. García de de Castro Andrews, A.; Garcia Carrodeguas, R.; Padilla Mondejar, S.; Acosta Contreras, N. Bone Regeneration Materials Based on Combinations of Monetite and Other Bioactive Calcium and Silicon. Compounds. Patent WO 2010092001 A1, 19 August 2010.

26. Padilla, S.; Benito-Garzón, L.; Sanz, S.E.; Garzón-Gutiérrez, A.; Carrodeguas, R.G.; Rodríguez, M.A.; De Castro, A.G.; Canillas, M. Novel Osteoinductive and Osteogenic Scaffolds of Monetite, Amorphous Calcium Phosphate, Hydroxyapatite, and Silica Gel: Influence of the Hydroxyapatite/Monetite Ratio on Their In Vivo Behavior and on Their Physical and Chemical Properties. ACS Biomater. Sci. Eng. 2020, 6, 3440-3453. [CrossRef]

27. García, S.P.A.; Garzón-Gutiérrez, D.C.A.; Enciso, L.B.S.; Padilla, S.; De Castro, A.G.; Garzón-Gutiérrez, A.; Benito, L.; Enciso, S.; Canillas, M.; Carrodeguas, R.G. Novel Nanostructured Zn-substituted Monetite Based Biomaterial for Bone Regeneration. J. Nanomed. Nanotechnol. 2015, 6. [CrossRef]

28. Hoppe, A.; Güldal, N.S.; Boccaccini, A.R. A review of the biological response to ionic dissolution products from bioactive glasses and glass-ceramics. Biomaterials 2011, 32, 2757-2774. [CrossRef]

29. Yamaguchi, M. Role of zinc in bone formation and bone resorption. J. Trace Elem. Exp. Med. 1998, 11, 119-135. [CrossRef]

30. Bose, S.; Fielding, G.; Tarafder, S.; Bandyopadhyay, A. Understanding of dopant-induced osteogenesis and angiogenesis in calcium phosphate ceramics. Trends Biotechnol. 2013, 31, 594-605. [CrossRef]

31. Lakhkar, N.J.; Lee, I.-H.; Kim, H.-W.; Salih, V.; Wall, I.B.; Knowles, J.C. Bone formation controlled by biologically relevant inorganic ions: Role and controlled delivery from phosphate-based glasses. Adv. Drug Deliv. Rev. 2013, 65, 405-420. [CrossRef] 
32. Seo, H.-J.; Cho, Y.-E.; Kim, T.; Shin, H.-I.; Kwun, I.-S. Zinc may increase bone formation through stimulating cell proliferation, alkaline phosphatase activity and collagen synthesis in osteoblastic MC3T3-E1 cells. Nutr. Res. Pr. 2010, 4, 356-361. [CrossRef]

33. Hadley, K.B.; Newman, S.M.; Hunt, J.R. Dietary zinc reduces osteoclast resorption activities and increases markers of osteoblast differentiation, matrix maturation, and mineralization in the long bones of growing rats. J. Nutr. Biochem. 2010, 21, 297-303. [CrossRef]

34. Moonga, B.S.; Dempster, D.W. Zinc is a potent inhibitor of osteoclastic bone resorption in vitro. J. Bone Miner. Res. 2009, 10, 453-457. [CrossRef]

35. Roy, M.; Fielding, G.A.; Bandyopadhyay, A.; Bose, S. Effects of zinc and strontium substitution in tricalcium phosphate on osteoclast differentiation and resorption. Biomater. Sci. 2012, 1, 74-82. [CrossRef]

36. Matena, J.; Petersen, S.; Gieseke, M.; Kampmann, A.; Teske, M.; Beyerbach, M.; Escobar, H.M.; Haferkamp, H.; Gellrich, N.-C.; Nolte, I. SLM Produced Porous Titanium Implant Improvements for Enhanced Vascularization and Osteoblast Seeding. Int. J. Mol. Sci. 2015, 16, 7478-7492. [CrossRef]

37. Maniatopoulos, C.; Rodriguez, A.; Deporter, D.A.; Melcher, A.H. An improved method for preparing histological sections of metallic implants. Int. J. Oral Maxillofac. Implant. 1986, 1.

38. Haas, R.; Donath, K.; Födinger, M.; Watzek, G. Bovine hydroxyapatite for maxillary sinus grafting: Comparative histomorphometric findings in sheep. Clin. Oral Implant. Res. 1998, 9, 107-116. [CrossRef]

39. Barakat, N.; Khalil, K.; Sheikh, F.A.; Omran, A.; Gaihre, B.; Khil, S.M.; Kim, H.Y. Physiochemical characterizations of hydroxyapatite extracted from bovine bones by three different methods: Extraction of biologically desirable HAp. Mater. Sci. Eng. C 2008, 28, 1381-1387. [CrossRef]

40. Chiapasco, M.; Gatti, C.; Rossi, E.; Haeflige, W.; Markwaldel, T.H. Implant-retained mandibular overdentures with immediate loading. Clin. Oral Implant. Res. 1997, 8, 48-57. [CrossRef]

41. Jaffin, R.A.; Berman, C.L. The Excessive Loss of Branemark Fixtures in Type IV Bone: A 5-Year Analysis. J. Periodontol. 1991, 62, 2-4. [CrossRef]

42. Lazzara, R.J.; Porter, S.S.; Testori, T.; Galante, J.; Zetterqvist, L. A prospective multicenter study evaluating loading of osseotite implants two months after placement: One-year results. J. Esthet. Dent. 1998, 10, 280-289. [CrossRef]

43. Szmukler-Moncler, S.; Salama, H.; Reingewirtz, Y.; Dubruille, J.H. Timing of loading and effect of micromotion on bone-dental implant interface: Review of experimental literature. J. Biomed. Mater. Res. 1998, 43, 192-203. [CrossRef]

44. Sinjari, B.; D’Addazio, G.; De Tullio, I.; Traini, T.; Caputi, S. Peri-Implant Bone Resorption during Healing Abutment Placement: The Effect of a $0.20 \%$ Chlorhexidine Gel vs. Placebo-A Randomized Double Blind Controlled Human Study. BioMed Res. Int. 2018, 2018, 1-13. [CrossRef]

45. Chemousova, S.; Epple, M. Bioactive bone substitution materials. Adv. Biomater. Devices Med. 2014, 1, 74-87.

46. Bose, S.; Roy, M.; Bandyopadhyay, A. Recent advances in bone tissue engineering scaffolds. Trends Biotechnol. 2012, 30, 546-554. [CrossRef]

47. Stevens, M.M. Biomaterials for bone tissue engineering. Mater. Today 2008, 11, 18-25. [CrossRef]

48. Turri, A.; Dahlin, C. Comparative maxillary bone-defect healing by calcium-sulphate or deproteinized bovine bone particles and extra cellular matrix membranes in a guided bone regeneration setting: An experimental study in rabbits. Clin. Oral Implant. Res. 2014, 26, 501-506. [CrossRef]

49. Dodde, R.; Yavuzer, R.; Bier, U.C.; Alkadri, A.; Jackson, I.T. Spontaneous Bone Healing in the Rabbit. J. Craniofacial Surg. 2000, 11, 346-349. [CrossRef]

50. Schmitz, J.P.; Hollinger, J.O. The critical size defect as an experimental model for craniomandibulofacial nonunions. Clin. Orthop. Relat. Res. 1986, 299-308. [CrossRef]

51. Sohn, J.-Y.; Park, J.-C.; Um, Y.-J.; Jung, U.-W.; Kim, C.-S.; Cho, K.-S.; Choi, S.-H. Spontaneous healing capacity of rabbit cranial defects of various sizes. J. Periodontal Implant Sci. 2010, 40, 180-187. [CrossRef]

52. Busenlechner, D.; Tangl, S.; Mair, B.; Fugger, G.; Gruber, R.; Redl, H.; Watzek, G. Simultaneous in vivo comparison of bone substitutes in a guided bone regeneration model. Biomaterials 2008, 29, 3195-3200. [CrossRef]

53. Murai, M.; Sato, S.; Fukase, Y.; Yamada, Y.; Komiyama, K.; Ito, K. Effects of Different Sizes of $\beta$-tricalcium Phosphate Particles on Bone Augmentation within a Titanium Cap in Rabbit Calvarium. Dent. Mater. J. 2006, 25, 87-96. [CrossRef]

54. Lundgren, A.K.; Lundgren, D.; Hammerle, C.H.; Nyman, S.; Sennerby, L. Influence of decortication of the donor bone on guided bone augmentation. An experimental study in the rabbit skull bone. Clin. Oral Implant. Res. 2000, 11,99-106. [CrossRef]

55. Stavropoulos, A.; Karring, E.S.; Kostopoulos, L.; Karring, T. Deproteinized bovine bone and gentamicin as an adjunct to GTR in the treatment of intrabony defects: A randomized controlled clinical study. J. Clin. Periodontol. 2003, 30, 486-495. [CrossRef]

56. Slotte, C.; Lundgren, D.; Burgos, P.M. Placement of autogeneic bone chips or bovine bone mineral in guided bone augmentation: A rabbit skull study. Int. J. Oral Maxillofac. Implant. 2003, 18, 795-806.

57. Figueiredo, M.; Henriques, J.; Martins, G.; Guerra, F.; Judas, F.; Figueiredo, H. Physicochemical characterization of biomaterials commonly used in dentistry as bone substitutes-Comparison with human bone. J. Biomed. Mater. Res. Part B Appl. Biomater. 2009, 92, 409-419. [CrossRef]

58. Jones, A.; Arns, C.; Sheppard, A.; Hutmacher, D.W.; Milthorpe, B.; Knackstedt, M. Assessment of bone ingrowth into porous biomaterials using MICRO-CT. Biomaterials 2007, 28, 2491-2504. [CrossRef] 
59. Lee, D.S.; Pai, Y.; Chang, S.; Kim, D. Microstructure, physical properties, and bone regeneration effect of the nano-sized $\beta$-tricalcium phosphate granules. Mater. Sci. Eng. C 2015, 58, 971-976. [CrossRef]

60. Trisi, P.; Rao, W.; Rebaudi, A.; Fiore, P. Histologic effect of pure-phase beta-tricalcium phosphate on bone regeneration in human artificial jawbone defects. Int. J. Periodontics Restor. Dent. 2003, 23, 69-78.

61. Yamauchi, K.; Takahashi, T.; Funaki, K.; Hamada, Y.; Yamashita, Y. Histological and histomorphometrical comparative study of $\beta$-tricalcium phosphate block grafts and periosteal expansion osteogenesis for alveolar bone augmentation. Int. J. Oral Maxillofac. Surg. 2010, 39, 1000-1006. [CrossRef]

62. Okada, Y.; Yamanaka, Y.; Menuki, K.; Zenke, Y.; Tsukamoto, M.; Tajima, T.; Kosugi, K.; Kawasaki, M.; Nakamura, E.; Toyota, N.; et al. Performance of two bone substitutes of novel cotton-like $\beta$-TCP/PDLGA and granular $\beta$-TCP on bone regeneration in the femoral bone defect of the Beagle dogs. Bone Rep. 2020, 13, 100718. [CrossRef]

63. Kokubo, T.; Takadama, H. How useful is SBF in predicting in vivo bone bioactivity? Biomaterials 2006, 27, 2907-2915. [CrossRef]

64. Osorio, R.; Alfonso-Rodríguez, C.A.; Osorio, E.; Medina-Castillo, A.L.; Alaminos, M.; Toledano-Osorio, M.; Toledano, M. Novel potential scaffold for periodontal tissue engineering. Clin. Oral Investig. 2017, 21, 2695-2707. [CrossRef] [PubMed]

65. Gorustovich, A.A.; Roether, J.A.; Boccaccini, A.R. Effect of Bioactive Glasses on Angiogenesis: A Review of In Vitro and In Vivo Evidences. Tissue Eng. Part B Rev. 2010, 16, 199-207. [CrossRef]

66. Webster, T. Enhanced functions of osteoblasts on nanophase ceramics. Biomaterials 2000, 21, 1803-1810. [CrossRef]

67. Oh, S.; Oh, N.; Appleford, M.; Ong, J.L. Bioceramics for Tissue Engineering Applications â€“ A Review. Am. J. Biochem. Biotechnol. 2006, 2, 49-56. [CrossRef]

68. Arcos, D. Calcium Phosphate Bioceramics. In Bioceramics with Clinical Applications, 1st ed.; Vallet-Regí, M., Ed.; John Wiley \& Sons Ltd.: Chichester, UK, 2014; pp. 25-71.

69. Dorozhkin, S.V. Nanodimensional and Nanocrystalline Calcium Orthophosphates. Am. J. Biomed. Eng. 2012, 2, 48-97. [CrossRef]

70. Webster, T.J.; Ergun, C.; Doremus, R.H.; Siegel, R.W.; Bizios, R. Enhanced osteoclast-like cell functions on nanophase ceramics. Biomaterials 2001, 22, 1327-1333. [CrossRef]

71. Tamimi, F.; Torres, J.; Kathan, C.; Baca, R.; Clemente, C.; Blanco, L.; Cabarcos, E.L. Bone regeneration in rabbit calvaria with novel monetite granules. J. Biomed. Mater. Res. Part A 2008, 87, 980-985. [CrossRef] [PubMed]

72. Tamimi, F.; Torres, J.; Bassett, D.; Barralet, J.; Cabarcos, E.L. Resorption of monetite granules in alveolar bone defects in human patients. Biomaterials 2010, 31, 2762-2769. [CrossRef]

73. Carlisle, E.M. Silicon: A Possible Factor in Bone Calcification. Science 1970, 167, 279-280. [CrossRef]

74. Mladenović, Ž.; Johansson, A.; Willman, B.; Shahabi, K.; Björn, E.; Ransjö, M. Soluble silica inhibits osteoclast formation and bone resorption in vitro. Acta Biomater. 2013, 10, 406-418. [CrossRef]

75. Lambert, F.; Leonard, A.; Lecloux, G.; Sourice, S.; Pilet, P.; Rompen, E. A comparison of three calcium phosphate-based space fillers in sinus elevation: A study in rabbits. Int. J. Oral Maxillofac. Implant. 2013, 28, 393-402. [CrossRef] [PubMed]

76. Torres, J.; Tamimi, F.; Tresguerres, I.F.; Alkhraisat, M.H.; Khraisat, A.; Bsc, E.L.; Blanco, L. Effect of Solely Applied Platelet-Rich Plasma on Osseous Regeneration Compared to Bio-Oss ${ }^{\circledR}$ : A Morphometric and Densitometric Study on Rabbit Calvaria. Clin. Implant. Dent. Relat. Res. 2007, 10, 106-112. [CrossRef] [PubMed]

77. Chakar, C.; Soffer, E.; Cohen, N.; Petite, H.; Naaman, N.; Anagnostou, F. Vertical bone regeneration with deproteinised bovine bone mineral or biphasic calcium phosphate in the rabbit calvarium: Effect of autologous platelet lysate. J. Mater. Sci. Mater. Electron. 2015, 26, 1-9. [CrossRef]

78. Mariño, F.T.; Torres, J.; Tresguerres, I.; Jerez, L.B.; Cabarcos, E.L. Vertical bone augmentation with granulated brushite cement set in glycolic acid. J. Biomed. Mater. Res. Part A 2006, 81A, 93-102. [CrossRef]

79. Carrel, J.-P.; Wiskott, A.; Moussa, M.; Rieder, P.; Scherrer, S.; Durual, S. A 3D printed TCP/HA structure as a new osteoconductive scaffold for vertical bone augmentation. Clin. Oral Implant. Res. 2014, 27, 55-62. [CrossRef] [PubMed]

80. Hallman, M.; Sennerby, L.; Lundgren, S. A clinical and histologic evaluation of implant integration in the posterior maxilla after sinus floor augmentation with autogenous bone, bovine hydroxyapatite, or a 20:80 mixture. Int. J. Oral Maxillofac. Implant. 2002, $17,635-643$.

81. Berglundh, T.; Lindhe, J. Healing around implants placed in bone defects treated with Bio-Oss ${ }^{\circledR}$. An experimental study in the dog. Clin. Oral Implant. Res. 1997, 8, 117-124. [CrossRef]

82. Carmagnola, D.; Adriaens, P.; Berglundh, T. Healing of human extraction sockets filled with Bio-OssR. Clin. Oral Implant. Res. 2003, 14, 137-143. [CrossRef]

83. Rompen, E.H.; Biewer, R.; Vanheusden, A.; Zahedi, S.; Nusgens, B. The influence of cortical perforations and of space filling with peripheral blood on the kinetics Of guided bone generation. A comparative histometric study in the rat. Clin. Oral Implant. Res. 1999, 10, 85-94. [CrossRef] [PubMed]

84. Schmid, J.; Wallkamm, B.; Hämmerle, C.H.F.; Gogolewski, S.; Lang, N.P. The significance of angiogenesis in guided bone regeneration. A case report of a rabbit experiment. Clin. Oral Implant. Res. 1997, 8, 244-248. [CrossRef] [PubMed]

85. Sennerby, L.; Meredith, N. Implant stability measurements using resonance frequency analysis: Biological and biomechanical aspects and clinical implications. Periodontology 2000 2008, 47, 51-66. [CrossRef] [PubMed] 